\title{
SCHOOL PSYCHOLOGIST'S INTERVENTIONS TO PROMOTE SUCCESSFUL SCHOOL RE-ENTRY OF CHRONICALLY ILL CHILDREN AIMING AT ALTERING PEERS' ATTITUDES TOWARDS THEM
}

\begin{abstract}
AвSTRAct. Nowakowska Iwona, School Psychologist's Interventions to Promote Successful School Re-Entry of Chronically ill Children Aiming at Altering Peers' Attitudes Towards Them [Psycholog szkolny wobec powrotu dzieci chorych przewlekle do szkoły - strategie zmiany postaw rówieśniczych]. Studia Edukacyjne nr 48, 2018, Poznań 2018, pp. 201-214. Adam Mickiewicz University Press. ISSN 1233-6688. DOI: $10.14746 /$ se.2018.48.13
\end{abstract}

The aim of this article is to outline school psychologist's interventions, which might be useful while supporting a chronically, somatically ill child in their re-entry to school, aiming at broadening their peers' knowledge about the chronic disease and positively changing their attitudes towards the ill child. In the first part, the importance of peer relationships in childhood and adolescence, the relation of their quality to school absences and the positive role of school attendance in the process of adaptation to illness and recovery, are presented. Then, the arguments for school psychologist to become an agent of child's positive school re-entry are provided. A framework of tasks to be performed by psychologist in the school setting is outlined. The second part focuses on the interventions which might be useful to meet expectations the environment has towards school psychologist in case of an ill child's return to school. Among them, negative messages' delivery, educational workshops design and delivery, promoting self-advocacy of the child, preventing violence and supporting child's siblings have been chosen as important areas of actions related to the child's peers. A selection of suggestions how to deal with these diverse fields of activity has been outlined, basing on re-entry models, as well as on useful directions and interventions to prevent bullying and support children in developing psychosocial competences, which are discussed in research reports, metaanalyses and professional literature.

Key words: school psychologist, chronically ill child, peers, school re-entry

\section{Introduction}

Chronic somatic illnesses - conditions which last more than three months and require medical attention as well as disturb a person's everyday life ${ }^{1}-$ are

${ }^{1}$ C. Barraclough, G. Machek, School Psychologists' Role Concerning Children With Chronic Illnesses in Schools, Journal of Applied School Psychology, 2010, 26, 2, p. 132. 
more and more frequently encountered among school students. Carol J. Kaffenberger enumerated most commonly occurring chronic somatic illnesses in school-aged children: asthma, cardiac diseases, seizure disorders, bleeding disorders, childhood cancers, inflammatory bowel disease, juvenile arthritis, cystic fibrosis, diabetes, sickle cell anaemia. ${ }^{2}$ This list is not complete, given that children may suffer from less common, although often equally debilitating and functionally affecting conditions.

Growing recognition of the fact of the increasing number of children affected with such long-lasting medical conditions contributes to research in the field of medicine, psychology and education. It also encourages practitioners in educational field to become agents of positive change of attitudes of school communities toward chronically ill pupils. Target groups within this community which might be supported, apart from ill students themselves are healthy children (ill child's peers), teachers, non-teaching school staff, parents, siblings of ill children and other members of their family.

In research literature mainly from the United States, among teachers and education specialists who play vital role in the process of somatically ill child's re-adaptation in school, psychologists are often seen as right persons to coordinate and take responsibility for the process of school re-entry and chronically ill child's adaptation in the peer group, due to their competences regarding child development, mental health and educational performance. ${ }^{3}$ Psychologists are also seen as a resource because of the training they obtained and skills they are expected to possess, such as data-based decision making, problem solving, progress monitoring and assessment, as well as team work.

A very important group to be targeted during psychologists' actions are the ill child's peers. Social functioning is found to be one of the main anxieties of a child returning to school after a period of illness-related absence. ${ }^{4}$ Peers inclined adversely toward this child may negatively contribute to their self-image, self-confidence and psychosocial development. This, overlapping with direct consequences of illness might be a stressor which a child can be unable to overcome on their own. Furthermore, the fear of being teased or socially excluded, experienced by an ill child is an important factor which contributes to extending absences and refusing to return to school despite overcoming the severe stage of illness. ${ }^{5}$

\footnotetext{
${ }^{2}$ C.J. Kaffenberger, School Reentry for Students with a Chronic Illness: A Role for Professional School Counsellors, Professional School Counselling, 2006, 9, 3, p. 224.

${ }^{3}$ See for instance C. Barraclough, G. Machek, School Psychologists' Role, p. 134.

${ }^{4}$ F.F. Worchel-Prevatt et al., A School Reentry Program for Chronically Ill Children, Journal of School Psychology, 1998, 36, 3, p. 262.

${ }^{5}$ Ibidem.
} 
The aim of this article is to outline practices that might be useful for a school psychologist as a person functioning as a teacher-specialist and equipped with knowledge regarding both biological and psychosocial development of children to encourage successful re-entry of a chronically somatically ill child into the peer environment.

\section{Peer group rejection and support: consequences for the chronically ill child}

Chronic illness affects many areas of human functioning. Apart from physical, mental and cognitive consequences which might occur (depending on the nature of the medical condition), social functioning is critically important while considering a child or teenager, for whom classmates are a crucial group of reference. Conforming to the standards of the group is referred to as a foremost task for a chronically ill child. ${ }^{6}$ In adolescence, a very special importance is given to the quality of peer relationships. Establishing friendships, sharing common tastes, identifying with some form of teenager style and learning coping strategies are mentioned as vital factors for the thriving of sense of connectedness and belonging. ${ }^{7}$

Quality of relationships with peers is a relevant measure of social functioning in childhood and adolescence and is a good predictor of social adjustment in future life. ${ }^{8}$ Chronic illness links with frequent absences in school, falling behind with the educational programme and with the group process inside the class taking place every day. Furthermore, it sometimes connects with an obligation to undergo medical procedures regularly, such as is the case of children with insulin-reliant diabetes, who, if necessary, need to have injections during school time. A risk of being rejected, teased or bullied by the peer group at school is higher given these arguments.

Research suggests that children are often apprehensive about their return to school after receiving diagnosis, lengthy hospitalisation or staying at home not due to their medical condition, but rather because of fearing the risk of social isolation and not being able to keep up with learning, as well as feeling ashamed of changes in physical appearance..$^{9}$ As indicated in studies, peer rejection connects with illness visibility. In a research conducted by Sara King et al. in Canada, healthy children had been given vignettes with hypothetical

\footnotetext{
${ }^{6}$ M. Jackson, The Special Educational Needs of Adolescents Living with Chronic Illness: a Literature Review, International Journal of Inclusive Education, 2013, 17, 6, p. 544.

${ }^{7}$ P. Foreman (Ed.), Inclusion in Action 3, South Melbourne 2011, p. 491.

${ }^{8}$ S. King, A.J. MacDonald, C.T. Chambers, Perceptions of Healthy Children Toward Peers With a Chronic Condition, Children's Health Care, 2010, 39, p. 200.

${ }^{9}$ F.F. Worchel-Prevatt et al., A School Reentry Program, p. 262.
} 
future somatically ill peers. They assessed ill children with directly visible medical conditions as less likable and not able to perform the same things as them..$^{10}$ Meanwhile, for teenagers it is developmentally characteristic to feel anxious about body image and identity (interconnected as they $\operatorname{are}^{11}$ ), as well as prospective role in the society. This might be augmented by chronic illness and its consequences, ${ }^{12}$ which is particularly acute given a struggle for possibly "normal" life on the one hand, and such a sound need to be like peers ${ }^{13}$ on the other. Research suggests that adolescent students experience the physical consequences of their illness so much that it is the most common reason to visit mental health specialist during school re-entry process. ${ }^{14}$ What is more, chronically ill children fear being asked intimidating questions about their illness and not knowing how to answer them. ${ }^{15}$

Given the importance of peer group and the indirect consequences that might occur in a somatically ill child due to peer rejection, it is crucial to plan re-entries to school and not leave these children to themselves. That is where school psychologists might have a valid opportunity to make use of their skills and fulfil their vocational role.

\section{Why is school psychologist the right person to introduce a positive change?}

Model interventions focused on school re-entry of a chronically ill child are widely discussed in school psychology literature. ${ }^{16}$ The main barriers that are reported to interfere with the smooth school re-entry process are lacks in: communication, information and training as well as school system policies being unsupportive. ${ }^{17}$

\footnotetext{
${ }^{10}$ S. King, A.J. MacDonald, C.T. Chambers, Perceptions, p. 207.

${ }^{11}$ J.W. Ross, S.A. Scarvalone, Facilitating the Pediatric Cancer Patient's Return to School, Social Work, 1982, 27, 3, p. 256.

${ }_{12}$ T. Ainsa, Teaching the Terminally Ill Child, Education, 1981, 101, 4, p. 400.

${ }^{13}$ J.W. Ross, S.A. Scarvalone, Facilitating, p. 256.

${ }^{14}$ S.B. Sexson, A. Madan-Swain, School re-entry for the child with chronic illness, Journal of Learning Disabilites, 1993, 26, 2, p. 118.

${ }^{15}$ Ibidem, p. 266.

${ }^{16}$ See for instance: C.H. Baskin et al., Helping Teachers Help Children with Cancer: a Workshop for School Personnel, Children's Health Care, 1983, 12; C.J. Kaffenberger, School Reentry for Students with a Chronic Illness: A Role for Professional School Counselors; M.A. Lopez, W.A. Rae, L. Frankel, A School Reentry Program for Chronically Ill Children, Journal of School Psychology, 1998, 36, 3; M.B. Sachs, Helping the Child with Cancer Go Back to School, Journal of School Health, 1980, 50; S.B. Sexson, A. Madan-Swain, School Reentry; F.F. Worchel-Prevatt et al., A School Reentry Program.

${ }_{17}$ C.J. Kaffenberger, School Reentry, p. 225.
} 
Frances F. Prevatt et al., after a comprehensive review of 16 model programs of school return of children with cancer, highlighted six components of these programs that boost the effectiveness of reintegration. Among them are:

1) identification of a coordinator of provided services - a member of school community and/or a medical team;

2) provision of direct services targeted at the ill student;

3) family consultations;

4) school personnel education;

5) provision of information to classmates of the child;

6) supporting the involvement of the medical staff. ${ }^{18}$

Due to the training received during studies and general knowledge about child development, educational performance and capabilities, as well as problem-solving and conflict management skills, school psychologists or school counsellors are seen as ideal agents of change and conductors of re-entry-supporting interventions in these models. ${ }^{19}$ A school psychologist has a very special, partly educational and partly clinical role and has to be equipped with rich knowledge and a variety of skills: ${ }^{20}$

1) knowledge of child and adolescent psychopathology and therapeutic skills which might be used in the school setting, such as behavioural interventions or short-term, basic psychotherapeutic skills in a chosen theoretical approach;

2) basic knowledge of forms of family therapy and conducting pre-therapeutic family interventions if necessary;

3) knowledge of educational achievement determinants and educational therapy competences;

4) ability to design and lead group workshops aimed at thriving soft skills as well as psychoeducational meetings for students, teachers and parents;

5) capability to mediate and/or supervise negotiations in case of conflict or misunderstandings within the school community;

6) knowledge about efficient methods of violent and problematic behaviours' prevention and intervening in case of their occurrence;

7) skills necessary to intervene in case of crisis (a crisis in the macrosystem of child functioning, such as national disaster; tragedy; a crisis at school; a personal crisis in a student's life);

${ }^{18}$ F.F. Prevatt, R.W. Heffer, P.A. Lowe, A Review of School Reintegration Programs for Children with Cancer, Journal of School Psychology, 2000, 38.

19 B.C. Grier, K.L. Bradley-Klug, Collaborative Consultation to Support Children With Pediatric Health Issues: A Review of the Biopsychoeducational Model, Journal of Educational and Psychological Consultation, 2011, 21, p. 90.

${ }^{20}$ See for instance M. Frost et al., Delivering and Receiving Bad News: What School Psychologists Need to Know, Journal of Applied School Psychology, 2010, 26, 3; G. Katra, E. Sokołowska (Eds.), Rola i zadania psychologa we wspótczesnej szkole, Warszawa 2010. 
8) knowledge necessary to provide informational support in case of psychological, emotional, social, educational difficulties;

9) cooperating with outer institutions.

Even though these expectations towards school psychology specialists are high, the role of psychologist while actually encountering a chronically ill child at school is not clear. ${ }^{21}$ Moreover, many counsellors do not feel adequately prepared to offer such a wide range of targeted services to both the ill child and their environment, including peers. ${ }^{22}$

In the following section a selection of useful interventions targeted at an ill child's peers, which correspond to the expectations towards the school psychologist mentioned above, is outlined.

\section{Review of interventions affecting peers}

Delivering bad news about the ill peer. In the United States, a growing number of school psychologists are expected to pass difficult news, such as messages about a death of a member of the school community or a disaster. ${ }^{23}$ In 2002, The National Association of School Psychologists in the United States issued a set of tips for both parents and teachers, indicating how to inform children and deal with uncomfortable messages' delivery, such as information about a natural disaster or a terrorist attack. ${ }^{24}$ Given that information about a diagnosis of a chronic illness of a student might be seen as a kind of bad, potentially traumatising news to be delivered by a member of the school staff, some of the suggested tips could be useful while being challenged with a necessity to pass such a message.

Amongst them we might highlight following hints:

1) to stay calm, tell the truth only and avoid speculating, so as to stick to the facts. Pretending that the event did not take place or underestimating its seriousness might be easily found out by children or enhance excessive or even false hope;

2) to ensure that the message is understandable for the children - that is where knowledge about cognitive and emotional development is crucial;

3) to encourage naming feelings and thoughts linked to the matter that occur in children's minds. That is cathartic and prevents consequences for

${ }^{21}$ C.J. Kaffenberger, School Reentry, p. 225; B.C. Grier, K.L. Bradley-Klug, Collaborative Consultation, p. 90.

${ }^{22}$ See for instance: C.J. Kaffenberger, School Reentry, p. 225.

${ }^{23}$ M. Frost et al., Delivering and Receiving Bad News, p. 208.

${ }^{24}$ National Association of School Psychologists, A National Tragedy: Helping Children Cope. Tips for Parents and Teachers. http://www.mccracken.kyschools.us/Downloads/Helping\%20 Children\%20Cope\%20after\%20a\%20National\%20Tragedy.pdf [access: 26.11.2017]. 
mental health. Therefore, creating a safe environment, either in group or providing children with a place for individual contact is also a very important task for the school psychologist, who is by definition obliged to be a good listener;

4) screening for children of high risk of developing trauma due to message reception. Some students might be more affected by the news heard due to their individual vulnerability, similarity of own experiences or some other reasons. Identifying and active reacting to first symptoms of distress, as well as offering psychological support when necessary seem to be vital.

To remain professional, after passing a difficult message, the psychologist needs to monitor their own emotions and level of stress. Keeping in contact with other members of school staff, as well as consulting a supervisor may be useful while encountering crises.

Educational workshops. Research has shown that chronically ill children's peers often have misconceptions about the illness which may turn out to be devastating for the child ${ }^{25}$ and increase a risk for teasing. School psychologists, equipped with academic knowledge of social psychology as well as skills necessary to design and deliver group workshops, may successfully become disseminators of what is actual and, indirectly, combat the stigma associated with the child's condition. The important limitation of this approach is the fact that psychologists might undertrained regarding less common pediatric illnesses which may affect children, as this is not of main focus of psychology curriculum. However, the task for all psychologists as agents of positive change in school is to educate themselves about the condition of their pupil. Only when even basic, but actual and up-todate knowledge is obtained by psychologist, should they start spreading it within the school community.

To educate the school environment about the illness, it is worth seeking for help in institutions and organizations which publish open-access brochures (often targeted to various age groups) that could be handed to the members of school community. Specialized organizations may also be helpful in designing educational intervention which would be informative, interesting and stigma-combatting. Creating a safe zone for asking questions and a possibility for peers to receive answers is a good idea to broaden their knowledge and prepare for the return of the student.

To achieve the desired effect, school psychologist's work with chronically ill child's peers may concentrate both on informative side of the meeting and on strengthening group coherence. Group coherence may be established when the person conducting a workshop implements a few useful strategies:

${ }^{25}$ F.F. Worchel-Prevatt et al., A School Reentry Program, p. 266. 
1) letting participants introduce themselves; establishing a common goal of work;

2) writing down a contract;

3) establishing and respecting a rule "reacting to all of the input of participants"; paraphrasing, summing up, referring to the students' comments;

4) not assessing any of the participants' utterances;

5) clarifying, interpreting;

6) broadening the meeting with psychological knowledge (lecture elements) and new skills (training elements);

7) summing up most important parts of group works;

8) gathering feedback from the participants in oral and written form. ${ }^{26}$

Promoting ill children's self-advocacy. Self-advocacy has an underlying assumption that every person should stand for their own about issues which apply to them. It is a skill to be learned virtually for every child - an ability to stand for himself or herself, to speak out about their needs and assertively communicate with their environment. Among persons with various disabilities, a self-advocacy movement is gradually gaining recognition worldwide. ${ }^{27}$ The motto of this approach is: "nothing about us without us". For instance, when designing something for a disabled person, we have to ask them for opinion, whether it really meets their expectations and needs. Another example concerns conducting meetings or workshops about disabilities and illnesses. If we wanted to be congruent the self-advocacy philosophy, the best way to properly design such events would be to invite a person affected by condition of interest, if not for the entire meeting, then for a part of it.

Becoming a fully-fledged self-advocate may be a lifelong process, however, we might apply the "nothing about a child without him/her" rule in school setting when considering a child with chronic illness. To help a child start being a self-advocate, we, as school psychologists or teachers, need to support him or her in gaining competences such as: knowledge of self (their interests, preferences, strengths, needs), knowledge of rights, communication and leadership skills. ${ }^{28}$ For instance, we may let the child introduce their peers to the illness and its features. In models of school re-entry, interventions of this kind have been proposed. Frances F. Worchel-Prevatt et al. in their

${ }^{26}$ E. Sokołowska, G. Katra, Praca z grupa na terenie szkoty, [in:] Rola i zadania psychologa we wspótczesnej szkole, Eds. G. Katra, E. Sokołowska, Warszawa 2010, p. 156.

${ }^{27}$ See for instance J. Caldwell, Leadership Development of Individuals with Developmental Disabilities in the Self-Advocacy Movement, Journal of Intellectual Disability Research, 2010, 54, 11, p. 1004; C. Zhang, 'Nothing About Us Without Us': the emerging disability movement and advocacy in China, Disability and Society, 2017, 32, 7.

${ }^{28}$ For instance using a framework developed by D.W. Test et al., A Conceptual Framework of Self-Advocacy for Students with Disabilities, Remedial and Special Education, 2005, 26, 1. 
suggested program of school return highlight an element of videotaping the hospital experiences for later sharing with the school community. They suggested a standard segment, generally educating about the hospital setting and illness encountered by the child and a second part, created by the particular chronically ill child. This element gave the children possibility to capture their unique experiences how they want it to be shown. Later on, a presentation was to be given by the child at school..$^{29}$ The authors of this model describe a case study of an Asian-American girl after cancer treatment, who was embraced by their suggested re-entry program, including the videotape presentation at school. They report that this event gave students possibility to ask her questions, clarified some misunderstandings and combatted myths existent in the school community. ${ }^{30}$

Although some parents may feel apprehensive about revealing the fact of chronic illness in family, the possible profits from coming out with information about it, including decreased fear of talking about illness and lower risk of peer teasing due to disease consequences, are obtainable. ${ }^{31}$ Lower level of perceived violence towards the ill child contributes to their more positive image of school and prevents excessive absences, which is important when considering the fact that school attendance influences school outcome and psychosocial development. ${ }^{32}$

Preventing violence. Violence at school is commonly occurring and has multiple facets. After the Internet gaining popularity and access to it being widened, a gradually increasing rate of e-violence is being observed. Violence against a chronically ill-child, suffering from fatigue, academic problems and/or having difficulties in coping with their condition may be of even increased risk of disturbing their well-being and even developing mental health problems. That is why violence prevention and counteraction is highlighted below as a special task of school psychologist to be performed and peer-targeted also in case of chronic illness of a member of school community.

Generally, school psychologist is bound to screen for symptoms of violence and be an agent of overcoming the problem. The trust that should be associated with the psychologist is crucial in order to intervene successfully and on time. Approach to choosing an appropriate prevention program to be implemented needs to be integrative and based on extensive knowledge about the features of the group as well as the nature of problem. ${ }^{33}$ Approaches such as Olweus

${ }^{29}$ F.F. Worchel-Prevatt et al., A School Reentry Program, p. 271-272, 274.

30 Ibidem, p. 275.

31 See for instance case study in: Ibidem, p. 273.

32 Ibidem, p. 265-266.

33 A. Piekarska, Przemoc i krzywdzenie "za szkolna brama" - programy psychoprofilaktyczne, [in:] Rola i zadania psychologa, p. 122. 
Program, ${ }^{34}$ Aggression Replacement Training by Goldstein et al. ${ }^{35}$ Non-Violent Communication by Rosenberg ${ }^{36}$ and workshops on psychosocial competences (assertiveness, negotiations, mediation, conflict management) led by school psychologists may be very useful while trying to prevent or manage an existent conflict and reduce the risk of violence reoccurrence. ${ }^{37}$

A model of coping with problem of interpersonal peer violence, which efficacy is highly rated by specialists ${ }^{38}$ is be a program developed by George Robinson and Barbara Maines - "No Blame". ${ }^{39}$ The program has been designed generally for all forms of peer mobbing at an early stage of its occurrence, however, can be successfully implemented while considering violence against groups with special needs. The main goal of the program is to develop empathy and therefore - deescalate the conflict. The agent of change in this approach is a support group, which consists of peers who mob and these who do not. During a meeting, a specialist discusses the harm being made to the victim and helps the peers understand the difficulty of the situation of the bullied student. The peers get tasks in order to control each other not to mob again. After this, regular monitoring of the victim, mobbing students and support group needs to be performed - until we are sure that mobbing has stopped and the student feels comfortable and is safe.

Sometimes, instead of systemic approach to the class, a mediation session is needed to work out a compromise between conflicted students. Importantly, the psychologist as a mediator needs to be impartial and neutral towards all sides of conflict and towards the solution. The whole procedure has to be confidential and voluntary. ${ }^{40}$ Mediation might be concentrated either solely on problem solving or on meliorating future relationships of the conflicted sides. ${ }^{41}$ These approaches stem from diverse theoretical orientations.

To solve the problem of conflict, students need to learn to:

1) recognize the features of the conflict in which they take part;

2) become aware of reasons and consequences of violence as well as of alternatives to violence, which can be useful even in situations of strong negative emotions;

3) try to solve conflict instead of avoiding it;

${ }^{34}$ D. Olweus, Mobbing - fala przemocy w szkole: jak ją powstrzymać, Warszawa 1998.

${ }_{35}$ A. Goldstein, B. Glick, Aggression Replacement Training: Curriculum and Evaluation, Simulation \& Gaming, 1994, 25, 1, p. 9-26.

${ }^{36}$ M. Rosenberg, Rozwiazywanie konfliktów poprzez porozumienie bez przemocy, Warszawa 2008.

${ }^{37}$ Ibidem, p. 121.

${ }^{38}$ See for instance S. Young, The Support Group Approach to Bullying in Schools, Educational Psychology in Practice, 1998, 14 - specialists rated the efficiency of intervention at $80 \%$.

${ }^{39}$ For a detailed description see: G. Robinson, B. Maines, Crying for Help. The No Blame Approach to Bullying, Bristol 1997.

${ }^{40}$ E. Czwartosz, Rola psychologa szkolnego wobec konfliktów, p. 136.

${ }^{41}$ Ibidem, p. 138. 
4) respect themselves and their interests as well as others and their interests; analyse interests of themselves and of others;

5) watch out for own prejudices, erroneous perceptions and evaluations and stereotypical thinking;

6) define contradictory interests as common problem to be solved;

7) be active listeners;

8) develop coping in difficult situations;

9) adhere to moral norms, take care of others, act fair. ${ }^{42}$

It is important to understand that conflicts are natural in groups of people - and school consists of a varied community with sometimes disparate needs. The best way to approach a conflict is to treat it as a problem to be solved. ${ }^{43}$ Support groups, suggested by George Robinson and Barbara Maines in "No Blame" program do well in groups of children who learn in primary and secondary schools. However, their usefulness is lower among high school students. ${ }^{44}$ Therefore, adhering to an integrative approach to anti-violence programs, school psychologist, working in cooperation with teachers and parents, needs to choose best intervention according to the context, recipients, nature and depth of the problem.

Support for siblings. Siblings of chronically ill child, who attend the same school are a special group of child environment. Their roles overlap, as they apart from being members of the same school community, are also members of the family, to which interventions are tailored accordingly. Children whose siblings suffer from chronic illness encounter emotional problems, connected with the stage of sibling's illness. Researchers report that in the period around diagnosis feelings of uncertainty, shock and disbelief are prevalent. ${ }^{45}$ Then, possibly feelings of sadness, anxiety, frustration, anger, sense of loss and many other negative emotions may occur. The emotional component of the problems that are likely to be encountered needs to be addressed in individual or family-centred work with the child's sibling - elements of crisis intervention, psychological support or psychotherapy, in severe cases, can be of value to promote well-being and adaptation to the sibling's medical condition.

Sometimes it may be observed in the school setting that siblings of a child with visible or widely known illness face social problems, being isolated from the rest. ${ }^{46}$ Maybe they are perceived as a part of the "difference" and "inadequ-

${ }^{42}$ See: M. Deutsch, P. Coleman, Rozwiązywanie konfliktów. Teoria i praktyka, Kraków 2005.

${ }^{43}$ E. Czwartosz, Rola psychologa szkolnego wobec konfliktów, p. 129.

${ }^{44}$ A. Piekarska, Przemoc i krzywdzenie "za szkolna brama", p. 124.

${ }^{45}$ M. Dobbie, D. Mellor, Chronic Illness and Its Impact: Considerations for Psychologists, Psychology, Health and Medicine, 2008, 13, 5, p. 586.

${ }^{46}$ L.L. Gan et al., School Experiences of Siblings of Children with Chronic Illness: A Systematic Literature Review, Journal of Pediatric Nursing, 2017, 33, p. 23-32. 
acy" of their sibling. That is where abovementioned interventions to combat the stigma of chronic illness may come in handy. However, the sibling may also seek help from the school psychologist in order to educate themselves in methods of coping and to gain knowledge about the illness itself, so that they begin to be an advocate of their sibling in the environment.

However, not all siblings experience isolation from peers. According to a metaanalysis by Lucy L. Gan et al., some of them encounter positive attitudes from their friends, who show interest about the state of health of their sibling and are a support. Social networks are a good predictor of adaptation to a new, threatening situation and may be a factor protecting from experiencing some mental disturbances ${ }^{47}$. That is also an argument for targeting peers to help them become a part of support network while dealing with matters of chronically ill child at school.

\section{Conclusions and recommendations}

The aim of this article was to outline the role of school psychologist in promoting successful re-entry to school of a child with chronic illness via interventions affecting peers of the child. The importance of peer relationships to well-being, process of adaptation to illness and recovery of the child is evident given the developmental characteristics of childhood and adolescence, as well as the fact that school is one of the most important places of socialization and an institution in which young people spend the majority of their time.

Given the role that the school psychologist is expected to play while functioning in school system, they seem to be the right persons to design and implement interventions not only targeting the child himself and the family, but also the peers. Firstly, the importance of delivering the message about illness in a sensitive way is a crucial starting point. Sensitivity and constant monitoring of the effect that the message evokes are foundations to following actions to be undertaken. Educational interventions, planned appropriately and prepared in consultation with other teachers can both positively affect class coherence and prevent bullying. If possible, supporting self-advocacy of a chronically ill child will be of benefit to their sense of agency and to the attitudes of peers. However, if a conflict occurs, usage of a properly selected remedial plan - either an anti-violence comprehensive program or a mediation session might help to solve existent problem.

${ }^{47}$ I. Heszen, H. Sęk, Psychologiczno-społeczny kontekst zdrowia i choroby, [in:] Psychologia zdrowia, Eds. I. Heszen, H. Sęk, Warszawa 2012, p. 166. 
Importantly, the presented solutions do not aspire to become a comprehensive model of a re-entry plan, given that a full model needs to take into consideration direct interventions targeted at a child and another crucial actors, such as parents and teachers. Rather than that, the outline above aims at highlighting the influence we might have on peers to affect their knowledge and behaviours toward a chronically ill child. Due to an alteration in their attitudes, we might contribute to well-being of the child and encourage re-establishment of friendships and development of peer support group, so important in the process of recovery and rehabilitation. Interventions that impact peers need to be a complementary part of wide-ranging re-entry standards and cannot be overlooked at any circumstances, due to a reciprocal nature of interactions between the ill child and other children belonging to the school community.

\section{BIBLIOGRAPHY}

Ainsa T., Teaching the Terminally Ill Child, Education, 1981, 101, 4.

Barraclough C., Machek G., School Psychologists' Role Concerning Children With Chronic Illnesses In Schools, Journal of Applied School Psychology, 2010, 26, 2.

Baskin C.H., Saylor C.F., Furey W.M., Finch A.J., Carek D.J., Helping Teachers Help Children with Cancer: a Workshop for School Personnel, Children's Health Care, 1983, 12.

Caldwell J., Leadership Development of Individuals with Developmental Disabilities in the Self-Advocacy Movement, Journal of Intellectual Disability Research, 2010, 54, 11.

Czwartosz E., Rola psychologa szkolnego wobec konfliktów. Dziatania profilaktyczne i interwencyjne, [in:] Rola i zadania psychologa we wspótczesnej szkole, Eds. G. Katra, E. Sokołowska, Wolters Kluwer, Warszawa 2010.

Deutsch M., Coleman P., Rozwiazywwanie konfliktów. Teoria i praktyka, Wydawnictwo Uniwersytetu Jagiellońskiego, Kraków 2005.

Dobbie M., Mellor D., Chronic Illness and Its Impact: Considerations for Psychologists, Psychology, Health and Medicine, 2008, 13, 5.

Foreman P. (Ed.), Inclusion in Action 3, Cengage Learning Australia, South Melbourne 2011.

Frost M., Rogers M.R., O'Bryon E.C., Hill Perry K., Delivering and Receiving Bad News: What School Psychologists Need to Know, Journal of Applied School Psychology, 2010, $26,3$.

Gan L.L., Lum A., Wakefield C.E., Nandakumar B., Fardell J.E., School Experiences of Siblings of Children with Chronic Illness: A Systematic Literature Review, Journal of Pediatric Nursing, 2017, 33.

Goldstein A., Glick B., Aggression Replacement Training: Curriculum and Evaluation, Simulation \& Gaming, 1994, 25, 1.

Grier B.C., Bradley-Klug K.L., Collaborative Consultation to Support Children With Pediatric Health Issues: A Review of the Biopsychoeducational Model, Journal of Educational and Psychological Consultation, 2011, 21.

Heszen I., Sęk H., Psychologiczno-społeczny kontekst zdrowia i choroby, [in:] Psychologia zdrowia, Eds. I. Heszen, H. Sęk, Wydawnictwo Naukowe PWN, Warszawa 2012.

Jackson M., The Special Educational Needs of Adolescents Living with Chronic Illness: a Literature Review, International Journal of Inclusive Education, 2013, 17, 6. 
Kaffenberger C.J., School Reentry for Students with a Chronic Illness: A Role for Professional School Counsellors, Professional School Counselling, 2006, 9, 3.

Katra G., Sokołowska E. (Eds.), Rola i zadania psychologa we współczesnej szkole, Wolters Kluwer, Warszawa 2010.

King S., MacDonald A.J., Chambers C.T., Perceptions of Healthy Children Toward Peers With a Chronic Condition, Children's Health Care, 2010, 39.

Lopez M.A., Rae W.A., Frankel L., A School Reentry Program for Chronically Ill Children, Journal of School Psychology, 1998, 36, 3.

National Association of School Psychologists, A National Tragedy: Helping Children Cope. Tips for Parents and Teachers. http://www.mccracken.kyschools.us/Downloads/Helping $\% 20$ Children $\% 20$ Cope $\% 20$ after $\% 20 \mathrm{a} \% 20$ National $\% 20$ Tragedy.pdf access date: 26.11.2017.

Worchel-Prevatt F.F., Heffer R.W., Prevatt B.C., Miner J., Young-Saleme T., Horgan D., Lopez M.A., Rae W.A., Frankel L., A School Reentry Program for Chronically Ill Children, Journal of School Psychology, 1998, 36, 3.

Olweus D., Mobbing - fala przemocy w szkole: jak ja powstrzymać, Jacek Santorski \& Co., Warszawa 1998.

Piekarska A., Przemoc i krzywdzenie "za szkolna brama" - programy psychoprofilaktyczne, [in:] Rola $i$ zadania psychologa we wspótczesnej szkole, Eds. G. Katra, E. Sokołowska, Wolters Kluwer, Warszawa 2010.

Prevatt F.F., Heffer R.W., Lowe P.A., A Review of School Reintegration Programs for Children with Cancer, Journal of School Psychology, 2000, 38.

Robinson G., Maines B., Crying for Help. The No Blame Approach to Bullying, Lucky Duck, Bristol 1997.

Rosenberg M., Rozwiązywanie konfliktów poprzez porozumienie bez przemocy, Jacek Santorski \& Co., Warszawa 2008.

Ross J.W., Scarvalone S.A., Facilitating the Pediatric Cancer Patient's Return to School, Social Work, 1982, 27, 3.

Sachs M.B., Helping the Child with Cancer Go Back to School, Journal of School Health, 1980, 50.

Sexson S.B., Madan-Swain A., School re-entry for the child with chronic illness, Journal of Learning Disabilities, 1993, 26, 2.

Sokołowska E., Katra G., Praca z grupa na terenie szkoty, [in:] Rola i zadania psychologa we współczesnej szkole, Eds. G. Katra, E. Sokołowska, Wolters Kluwer, Warszawa 201.

Test D.W., Fowler C.H., Wood W.M., Brewer D.M., Eddy S., A Conceptual Framework of Self-Advocacy for Students with Disabilities, Remedial and Special Education, 2005, 26, 1.

Young S., The Support Group Approach to Bullying in Schools, Educational Psychology in Practice, 1998, 14.

Zhang C., 'Nothing About Us Without Us': the emerging disability movement and advocacy in China, Disability and Society, 2017, 32, 7. 